\title{
Brief Biography of Robert Louis Stevenson
}

Robert Louis Stevenson was born on 13 November 1850 in Edinburgh, the only child of Margaret Balfour and Thomas Stevenson. Following the tradition of his family of lighthouse-builders, he first studied engineering, before switching to law (he qualified, but did not practise). A traveller throughout his life, the young Stevenson took a canoe trip in France, recorded in An Inland Voyage (1878) and a walking tour of the Cévennes: Travels with a Donkey (1879). By this time Stevenson had met Fanny van de Grift Osbourne, an older, married American woman, and, when she had divorced her husband, he set off in 1879 to join her in California, writing up their exploits as The Silverado Squatters (1884). His earliest success came with Treasure Island (1883). The Stevensons divided their time between Scotland, England and France, trying various locations for the sake of Louis's continued poor health, and settled in 1885 in Bournemouth. Here Louis developed his friendship with Henry James and wrote A Child's Garden of Verses, Prince Otto and, with his wife, The Dynamiter (all 1885). Strange Case of Dr Jekyll and Mr Hyde and Kidnapped followed in 1886.

After the death of Thomas Stevenson in 1887, the Stevensons left for America, and from there began their journeys among the Pacific Islands, buying an estate, Vailima, on Samoa. Stevenson's work was now published first in America, and included The Master of Ballantrae (1889) and The Wrecker (1892). In 1890 the family, including Fanny's son Lloyd Osbourne, decided to live permanently at Vailima. Stevenson became involved with Samoan politics and wrote A Footnote to History (1892) in protest at colonial exploitation of the region. The 1890s saw the publication of his great South Seas works: In the South Seas (1896), Island Nights' Entertainment (1893) and The Ebb-Tide (1894). Stevenson died of a cerebral haemorrhage on 3 December 1894, leaving unfinished his last novel, Weir of Hermiston (1896). 
